\title{
Farmers' Perception about the Use of Sorghum (Sorghum bicolor (L.) Moench) Landraces and Their Genetic Erosion in South Wollo Administrative Zone, Ethiopia
}

\author{
Silamlak Birhanu Abegaz ${ }^{1}{ }^{1}$ and Faris Hailu Tessema ${ }^{2}$ \\ ${ }^{1}$ Woldia University, Faculty of Natural and Computational Sciences, Department of Biology, P.O. Box 400, Woldia, Ethiopia \\ ${ }^{2}$ Wollo University, College of Natural Science, Department of Biology, Personal P O Box 1022, Dessie, Ethiopia \\ Correspondence should be addressed to Silamlak Birhanu Abegaz; silamlakb@wldu.edu.et
}

Received 25 February 2020; Revised 22 September 2020; Accepted 4 March 2021; Published 15 March 2021

Academic Editor: David Clay

Copyright (C) 2021 Silamlak Birhanu Abegaz and Faris Hailu Tessema. This is an open access article distributed under the Creative Commons Attribution License, which permits unrestricted use, distribution, and reproduction in any medium, provided the original work is properly cited.

\begin{abstract}
Genetic erosion can result in the loss of sorghum landrace genetic diversity. In the study areas, although it is generally believed that genetic erosion had occurred, there are no data on its amount and extent. Thus, this study is aimed to assess farmers' perception about the use of sorghum landraces and their genetic erosion and to identify suggested reasons for the replacement of sorghum landraces. To this end, a field survey of 1200 farmers, randomly selected over the three districts (Tenta, Mekdela, and Delanta) during 2006 to 2015/2016 main cropping seasons, was undertaken. Structured questionnaire survey of households, focused group discussions, key informant interviews, and field observations were used to collect data. Moreover, the data for samples collected during 1980 were obtained from the Ethiopian Biodiversity Institute (EBI). Sorghum landrace history profile analysis indicated that there was an insight in the use of local varieties among local farmers over the past three or above decades. However, there is a reduction trend due to the different selection criteria described by farmers. "Kokita," "Merar," "Marchuke," "Tinkish" (except for "Necho-Tinkish" and "Jofa-Tinkish"), and "Fesho" were totally excluded (lost) by local farmers attributed by home consumption preferences. The interviewed farmers indicated that genetic erosion had occurred. Genetic erosion of $100 \%$ was observed in white sorghum in Mekdela and $66.7 \%$ in Delanta and Tenta districts. Likewise, genetic erosion of red sorghum, 25\%, 20\%, and 75\%, respectively, was detected in Tenta, Mekdela, and Delanta. For yellow sorghum grains, genetic erosion was $33.4 \%$ in Tenta and 66.7\% in Mekdela and Delanta. Genetic erosion for "Tinkish" was found to be $66.7 \%$ in Tenta and 50\% in Mekdela and Delanta. Based on farmer responses, genetic erosion was attributed to reduced benefits from landraces, drought, climate change, market price and demand, and reduction in land size. The actions of both natural and conscious selection on farm were also discussed in detail as genetic erosion scenarios. Therefore, attention should be given to conservation of farmers' varieties in which involving farmers' participation is very important in order to use their indigenous knowledge for conservation of FVs and on-farm conservation strategies should be practiced for FV sustainable use. Thus, genetic resource conservation is attained.
\end{abstract}

\section{Introduction}

For several economically important cereals such as sorghum (Sorghum bicolor (L.) Moench), wheat (Triticum spp.), and barley (Hordeum spp.), Ethiopia is considered as center of diversity $[1,2]$. Sorghum (Sorghum bicolor (L.) Moench) is a cereal plant member of the family of Poaceae [3]. It is the fifth most important cereal in the world after maize, rice, wheat, and barley [4] with a worldwide production estimated to 60 million tons per year on cultivated area of 46 million hectares [5], and it is the main source of food, energy, and beverages for millions of people in arid and semiarid environments $[3,4]$. In the year 1794, Moench established the genus Sorghum and brought all the sorghums together under the name Sorghum bicolor $[6,7]$. However, Harlan and de Wet [8], using inflorescence type as a grouping criterion, divided all the cultivated sorghum taxa into five races and fifteen intermediate races, under S. bicolor ssp. bicolor. Four of the five major races of the cultivated sorghum 
and one intermediate race are found in Ethiopia [9]. Agriculture in Ethiopia is predominantly traditional, and thus, mainly field crop landraces are grown [10]. Landraces have a certain genetic integrity. They are recognizable morphologically; farmers have names for them, and different landraces are understood to differ in adaptation to soil type, time of seeding, date of maturity, height, nutritive value, use, and other properties. Most importantly, they are genetically diverse. Such balanced populations-variable, in equilibrium with both environment and pathogens, and genetically dynamic-are our heritage from past generations of cultivators. They are the result of millennia of natural and artificial selections and are the basic resources upon which future plant breeding must depend [11]. Cereal crop landraces are the genetic bases for further breeding works. Cereal crop landraces including sorghum may also be low yielding, but they are adapted to sowing, weeding, and harvesting procedures of traditional agriculture [12, 13]. Thousands of genetically distinct varieties of our major food crops owe their existence to years of evolution and to careful selection and improvement by our farmer ancestors. The value of sorghum landraces can be judged by their persistence in farming systems where alternative varieties exist as other cereal crops do [14]. In the field of plant genetic resources for food and agriculture, the irreversible loss of single genes, or combinations of genes in genotypes, the so-called gene erosion is of major concern. Various authors have defined genetic erosion as the loss of genetic diversity and commonly refer to the reduction in the quantities of specimens of a species [15]. It is also defined as the loss of variability from crop populations in diversity centers, i.e., areas of domestication and secondary diversification [16], or it is a loss of genes or alleles (narrow sense) as well as the loss of varieties (broad sense) [17]. Genetic erosion may occur at three levels of integration: crop, variety, and allele [18], and several approaches have been employed to estimate the degree of genetic erosion that a particular taxon faces in a certain region over a given time. Some other methods usually rely on the analysis of molecular data [19] and allozyme analysis [20], or comparison between the number of species/ cultivars still in use by farmers [21], using the genetic assessment model presented by Guarino [22], or using a checklist of risk factors [23]. However, the most widely used figures in estimating genetic erosion are indirect, i.e., the diffusion of modern crop varieties released from crop breeding programs. To reverse the unabated gene erosion, conservation of varietal profile is a fundamental concern. Further research on crop genetic resource management is indispensable for wise use of landraces, and particularly, research on traditional sorghum crops helps to develop sustainable conservation strategies. Noticing and assessing genetic erosion has been advocated as the first urgency need in any major effort to pause loss of genetic diversity. The threat of loss of crop genetic diversity at an alarming rate has long been recognized in Ethiopia $[2,24,25]$. Consequently, various exploration and rescue collections have been made to conserve cereal crop landraces and wild relatives, and these are commonly maintained under ex situ conditions [26]. The Ethiopian Sorghum Improvement Program (ESIP) has been involved in documenting and collecting sorghum landraces in Ethiopia for conservation and breeding purposes $[27,28]$. As inconsistent to the center of origin of sorghum, in Ethiopia, where it was domesticated $[29,30]$ and diversified [31], traditional sorghum varieties were decreased. One of the factors resulting in the loss of crop genetic variability is reduction in population size through the decline of plant number, so-called bottleneck effect [32]. Smaller populations are vulnerable to demographic and environmental fluctuations and the decline in fitness associated with genetic drift and inbreeding [33]. Traditional low-yielding cultivars adapted to optimal local agronomic conditions are probably the crop plant genetic resources that are most at risk of future loss from traditional societies through habitat destruction or by replacement by introduced influential germplasm [14]. Studies have been also carried out in the center of diversity Ethiopia, in order to evaluate the existence of genetic erosion on sorghum landraces, there is a clear evidence for no reduction in the number of sorghum landraces grown, Mekbib [13], and those studies only used samples from eastern parts of the country. Generally, nevertheless, many national programs have not regarded quantification of genetic erosion as a high priority, as apparent from the paucity of information in the state of the world report [34]. Nothing is known about the long-term effects of genetic erosion of sorghum landraces in the study areas. Thus, the overall objectives of the present study were as follows: (a) to assess farmers' perception about the use of sorghum landraces and their genetic erosion (b) to quantify the extent of genetic erosion and (c) to identify suggested reasons for the replacement of sorghum landraces.

\section{Materials and Methods}

2.1. Description of Study Area. There are 24 woredas in South Wollo Administrative Zone, Amhara Regional State. However, for this study, Delanta, Tenta, and Mekdela districts (Figure 1) were selected based on the criteria used by Mekbib [13]. Therefore, the reasons to assess genetic erosion of sorghum landraces in the study areas were as follows: (i) over the past three or above decades, there have been changes in farming systems to modify the diverse, weak, and risk crop production fields; hence, a variety of crops have been introduced to the farming community, (ii) the change of socioeconomic situations has an inference on the cropping pattern thereby on the on-farm genetic resource conservation, (iii) the change of climatic conditions for sorghum growing areas might have changed the type of crops used to be grown and (iv) the impact of biotic and abiotic stresses, and (v) there was no known similar study of any kind that was done before in the study area thereby used as a baseline reference. In Ethiopia, the variation in climate is traditionally divided into three main climatic zones: Dega, Weyna Dega, and Kolla. The first of these, Dega, refers to coldish, less than temperate zones with altitudes ranging between 2,600 and 3,200 meters above sea level (masl). The second zone, Weyna Dega, is warm and wet and lies below 2,600 meters above sea level (masl). The last, Kolla, is drier (and much warmer) than Weyna Dega. As a result of its position and varied topography, the climatic zone varies in South Wollo administrative Zone, broadly speaking, tropical in low lands and temperate and cool in the highlands. Temperatures in the tropical lowlands average out at around 


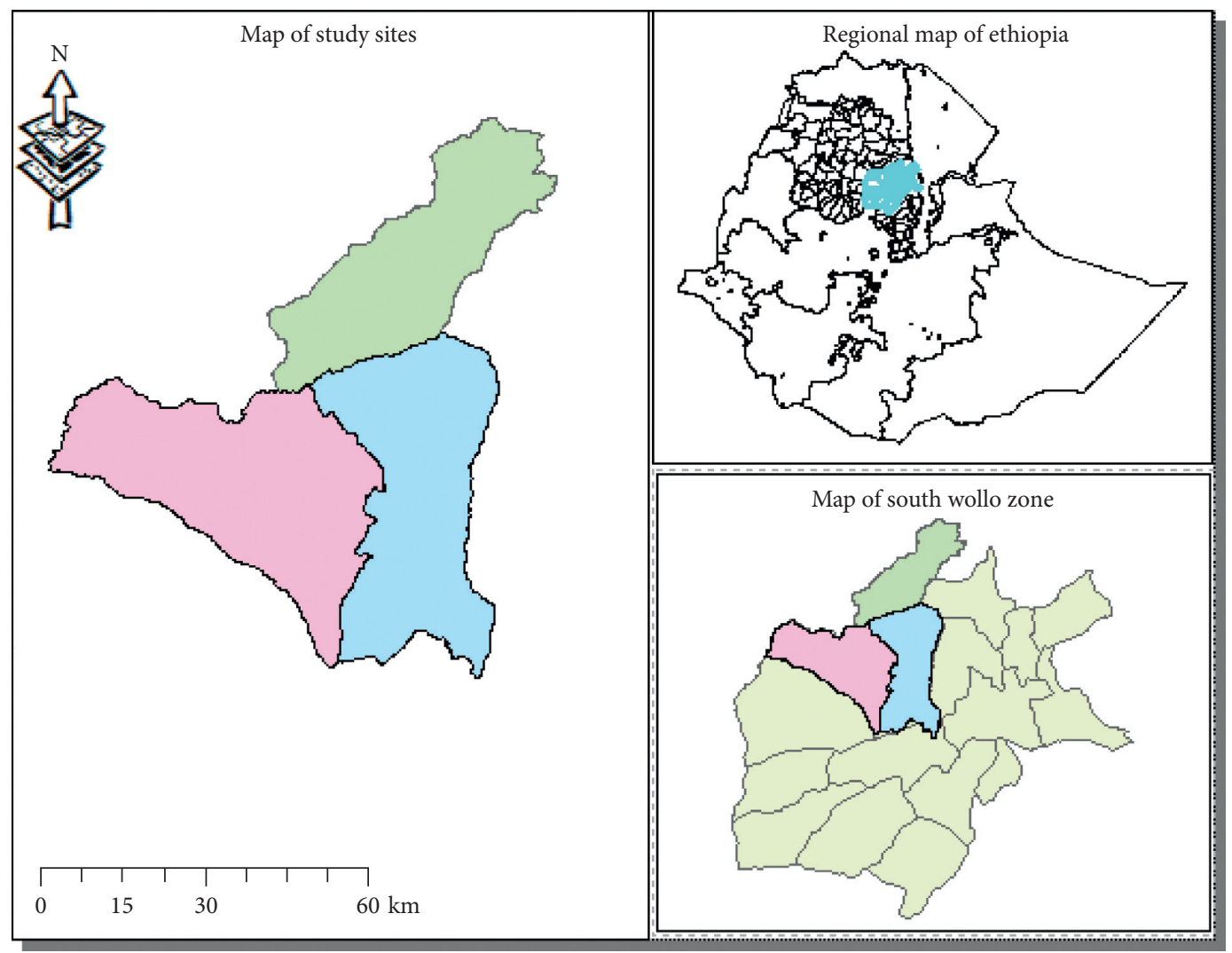

Woreda_name
\begin{tabular}{|l}
$\square$ \\
Delanta \\
$\square$ Mekdela \\
$\square$ Tenta
\end{tabular}

Figure 1: Map of Ethiopia (above right), South Wollo Zone (below right), and study sites (left side).

$27^{\circ} \mathrm{C}$, while those in the highlands are dependent on altitude, and range between 16 and $22^{\circ} \mathrm{C}$. The areas have two periods of rainfall, a short one (Belg), from February to April/May, and the main one (Kiremt), from June to September, as Woreda Agriculture and Rural Development Offices reported. For Delanta, the location is $10^{\circ} 19^{\prime} \mathrm{N}$ altitude and $39^{\circ} 15^{\prime}$ E longitude, bordered by the Beshilo River in the south, Dawunt Woreda in the west and on the northwest by Wadla, and Guba Lafto Woreda in the northeast and east. The major town is Wogeltena, which is situated $481 \mathrm{~km}$ from Addis Ababa, $290 \mathrm{~km}$ from Bahir Dar, and $80 \mathrm{~km}$ from Dessie. Tenta also has a latitude and longitude of $11^{\circ} 19^{\prime} \mathrm{N}$ $39^{\circ} 15^{\prime} \mathrm{E}$ with an elevation of 2,972 meters above sea level (masl). It is located $521 \mathrm{~km}$ from Addis Ababa and $120 \mathrm{~km}$ from Dessie, the major town is Adjibar. Mekdela is another part of South Wollo Zone, it is bordered on the southwest by the Walo Shabatala River which separates it from Sayint, on the west by Semien Gondar Zone, on the north by the Bashilo River which separates it from the Semien Wollo Zone, and on the east by Tenta. The major town in Mekdela is Masha. It is located $534 \mathrm{~km}$ from Addis Ababa and $133 \mathrm{~km}$ from Dessie, and it has latitude and longitude of $11^{\circ} 30^{\prime} \mathrm{N}$ $38^{\circ} 45^{\prime}$ E. Furthermore, these three small administrative units were adjacent and share common agroclimatic features.
According to CSA [35] estimation, total population of the districts was $127,771,142,654$, and 112,220 for Delanta, Mekdela, and Tenta, respectively. The inhabitants of the study areas were mostly members of the Amhara ethnic community who speaks the Amharic language and have different religion (in dwindling order of existence), age group (18-60 on average), and educational level, mostly illiterate to literate (Table 1). The economies in the areas were predominantly relies on rain-fed subsistence cultivation of mixed crops and livestock production. The land of the study areas was characterized by mountainous, plain, undulating hills, and valley sides. The areas were also highly populated and cultivated for a long period of time, so that the environments were vulnerable to various actions of human and natural interferences. As a result, the present environmental degradation reveals the effect of age-old exploitation of soil, tree cutting, and over grazing.

2.2. Research Design. The study was conducted in three administrative woredas with descriptive research design; particularly, the survey method and observational method were employed. In survey method research, participants would answer questions administered through interviews or questionnaires. With the observational method, there are 


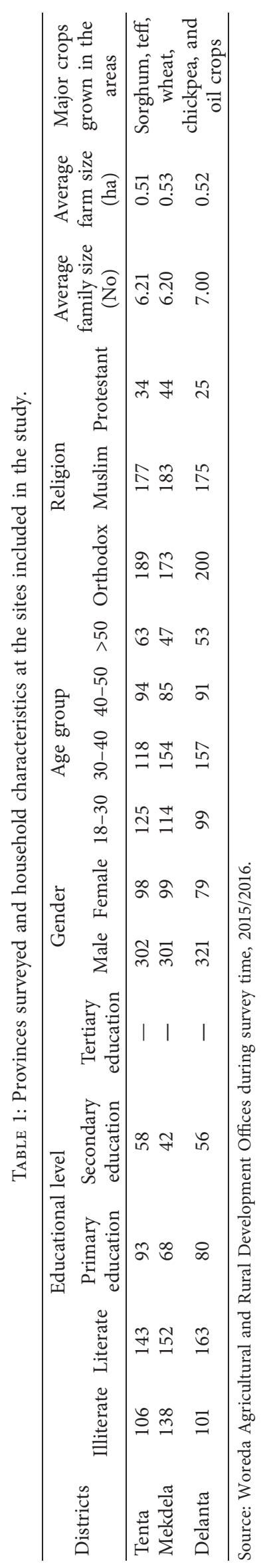


two main categories of the observational method: naturalistic and laboratory observations. For this study, naturalistic approach was employed.

\subsection{Sample Size and Sampling Techniques. Irrespective of its} ecological spectrum, sorghum production was not practiced (none) in highland and intermediate areas. Then, within each district, only 10 kebeles have a potential for sorghum production and hence were selected purposively for the study. First, ten Kolla kebeles (low land areas), Yederek, Robit, Wata, Sholaw, Bila, Chacha, Meguat, Debek, Tedat, and Yemt in Tenta Woreda; Mingash, Bazura, Wogessa, Yewotet, Asol, Warkaye, Tork, Gedam, Adada, and Tinbua in Mekdela Woreda; and Ziban Arehula, Wotege Aberkut, Zita, Shekol Senbeletkola, Asim Yimara, Keda Mistnkir, Goshmeda, Ferkake, Kisatkola, and Tikshign in Delanta Woreda were selected to make the sample representative of all the districts with Kolla agroclimatic zones for the study. Secondly, the required household head sample size was determined based on the population; proportional allocation was made for each kebele (40 households per kebele). During household sample determination, leaders of kebele for administrative and development agents (DAs) working in each kebele assisted in providing the list of farmers who lived more than three decades in each farming community. In order to represent all groups, based on sex, religion, education, and age, participants were selected from the lists. In addition, based on recommendations by farmers and development agents, local seed experts were identified and incorporated in the sample. Large and small land holder farmers, household heads of both sexes and different age groups, based on their availability, willingness, and indigenous knowledge on uses and genetic erosion of sorghum landraces in the study area, were considered. One thousand two hundred randomly selected households, that is, 924 males and 276 females (Table 1), were involved in a household questionnaire survey from the three districts.

\subsection{Data Collection Instruments. Focused group discussions} and key informant interviews: focused group discussions (a small, carefully selected group, homogenous in social composition) were carried out with 35-40 farmers in each study area that was divided into 5 groups including 8 to 13 people. The local administrators and DAs were encompassed and helped in identifying the names of the focused group in which different religion, age, gender, classes, and educational levels were considered. Issues related to conservation practices of still extant sorghum landraces, folk description and morphological characterization of local sorghum varieties, and different applications of local sorghum varieties: for example, animal feed, construction purposes, fire wood purposes, and food consumption at home such as "Injera" (flat pancake bread), "Kita" (flat steamed bread), boiled grain, roasted grain, porridge, and local drink "Tella" (prepared from fermented grains) were the hottest and raised during the discussions. Besides, formal and informal discussions on the insights of farmers' about use and genetic erosion of sorghum landraces were performed. In addition to focused group discussions, interviews with key informants (farmers recommended by the farming community for their rich indigenous technical knowledge on sorghum landrace production, management, and utilization) and development agents (DAs) were carried out to complement the information obtained from individual farmers' as well as focused group discussions. Furthermore, key informants were asked about the meaning of local names in cases when there were special attributes associated with the names. Key informants were also reflecting the popularity, distribution, and sociocultural (traditional) importance of sorghum landraces. Moreover, wealth of traditional sayings, poems, and songs were interviewed to obtain a picture of the importance of sorghum in society's daily life and expressions linked with sorghum production. For example, in Amharic language, they said that "Chibna Wulsera Egrun Lemagedo Erasun Le Tella" which means the head (grain) part is used for preparing local drink "Tella" and the stalk for fire wood. These approaches were some of the methods used for grasping insights of farmers about sorghum landrace uses and suggesting possible reasons for genetic erosion of the landraces. Key informant interview and focused group discussions were conducted during the main cropping season, from 2006 to 2015/2016. Moreover, information about the number of sorghum landraces collected during 1980 was obtained from the Ethiopian Biodiversity Institute (EBI).

Farmers' field observation: using checklist, visualizing agro ecology and cropping patterns of sorghum landraces and photos were taken. All accessions and species encountered were counted but if some of the accessions/or species were not observed, the farmers were asked about its presence/absence in previous years. Farmers' field observation along with questionnaire survey was done around the harvesting, threshing time, and physiological maturity of sorghum landraces.

Survey questionnaires: they can be used to assess the perception of individual farmers about use of sorghum landraces and presence or absence of genetic erosion was adapted from Hailu [36].The prepared questionnaires were also used to quantify and compare the data about genetic erosion of sorghum landraces. Multifarious questions that comprised of a Likert scale responses on a scale from 1 to 5 or yes or no were used to evaluate perception of farmers about the detail information of sorghum landraces. The questions were translated into local language (Amharic) by language experts to make it ease and clear for participants. With regard to households, questionnaires were supportively filled if there are illiterate samples. The farmers were asked about whether they still grow sorghum landraces on their farm or not, and if they grow or not, they were asked to give the reasons for growing/not growing these sorghum landraces. The questionnaires also assess why the farmers still favor to grow landraces or not and converted into a standard form for further analysis after assembling their responses. Factors and variables of importance for farmers' choice of growing sorghum landrace or not were calculated following the methodology of [37]. Factor analysis was performed for each question to identify the fundamental 
concepts from items of the question and the mean scores from the common concepts that were used in the general linear model analysis according to [38] by using statistical package SAS [39]. The qualitative data were analyzed by narration. Data were first checked manually for completeness and then coded and entered. Household survey and temporal (time) comparative quantitative methods were used to quantify genetic erosion of the different local sorghum varieties by using the approaches of Brush [14] and Mekbib [13]. In the comparative quantitative method, collections of sorghum landraces done by the EBI in 1980 and collections from the three districts in 2006-2015/2016 provided the temporal (time) method to quantify genetic erosion. Genetic integrity and erosion were calculated according to Hammer et al. [21].

\section{Results and Discussion}

3.1. Farmers' Perception about the Use of Sorghum Landraces and Their Genetic Erosion. As mentioned by local farmers, sorghum is a multiple value crop. Different parts of the plant are used for many purposes. There is nothing plowed back to the soil. Leaves are used for animal feed, the stem is for fuel, and construction and stumps are removed and used for fuel. The stem is piled and stalked for a few seasons to be used as fuel. Sometimes farmers get better prices in winter by selling stalks for fuel than selling sorghum grain in the market. The way the residue is collected and managed indicates how the livelihood of farmers is attached with sorghum. Mutegi et al. [40] also indicated that sorghum is used for food (as grain and syrup or "sorghum molasses"), animal fodder, production of alcoholic beverages, biofuels, and a staple food particularly for poor and rural people. However, farmers have been more risk liable and factors such as more frequent drought and unreliable rainfall, and increased pest infestation, late maturing, agronomic value, and consumption preferences have been contributed to a change in farmer landrace selection [18]. The result of the present study was shown that majority of farmers were growing sorghum landraces for home consumption (98.2\%). About $47.0 \%$ of the farmers produced sorghum landraces for sale as a seed when they have excess as grain and $8.6 \%$ for fire wood and construction purposes (Table 2). The seed exchange networking system was very poor in all surveyed areas, thus worsening seed preservation within the farming communities. However, some farmers (13.2\%) use sorghum for exchange with their neighboring farmers or relatives. The farmers often do such seed exchange when there is a sorghum landrace they want to grow but not in their hands or for other crops. Sorghum grain in the study areas is used primarily in the home to prepare local foods such as "Injera" (52.8\%), porridge and bread ("Kita") (49.4\%), and any other dietary functions. "Injera" is a leavened, round, and flat pancake which is a common diet of the three small administrative units. The type of grain sorghum used for "Injera," bread, and porridge has a slightly different from woreda to woreda and across different kebeles. Normally, "Zengada" (98.2\%) and "Chibna" (74.5\%) were preferred local sorghums for "Injera" because it gives the desired color
TABLE 2: Frequencies of local farmers citing the main purposes for growing local sorghum grains in the study areas.

\begin{tabular}{|c|c|c|c|c|}
\hline \multirow{2}{*}{ Main purpose } & \multicolumn{3}{|c|}{ Districts } & \multirow{2}{*}{$\begin{array}{c}\% \\
\text { utilization }\end{array}$} \\
\hline & Tenta & Mekdela & Delanta & \\
\hline Sale as a seed & 240 & 105 & 219 & 47.0 \\
\hline $\begin{array}{l}\text { Fire wood and } \\
\text { construction }\end{array}$ & 34 & 26 & 43 & 8.6 \\
\hline Exchange as a seed & 61 & 53 & 45 & 13.2 \\
\hline Keep as own seed & 325 & 399 & 349 & 89.4 \\
\hline For home consumption & 400 & 389 & 390 & 98.2 \\
\hline For animal feed (leaves) & 15 & 20 & 25 & 5.0 \\
\hline
\end{tabular}

Source: local farmers during survey time, 2015/2016. Note: there were multiple answers provided by farmers.

and taste, while "Wetere," the second most preferred local sorghum (83.2\%), is used for brewing a local alcoholic beer called "Tella." In general, households are slightly inclined to use "Zengada" for "Injera" and bread or porridge in the districts, hence mostly grown by local farmers (Table 3). More importantly, farmers both in the household interviewed and group discussion confirmed that they do not use sorghum only for one specific form of food preparations. Thus, the criteria used by farmers to plant sorghum landraces varied. Of course, there was a high demand for other crops that had higher yields. Harlan [11] claimed that field crop landraces are the products of human selection for characteristics color, taste, and texture and storage quality. Therefore, interestingly, these characteristics are commonly used by the farmers of the study areas in naming and consumption of sorghum landraces. Hawkes [41] also reported that the complex morphological variations that we see today are the result of the thousands of years of human activities of isolation, selection, and hybridization.

Farmers of the study area gave different vernacular names for sorghum landraces by using different criteria based on morphological and/or folk classification (Table 3 and Figures 2 and 3). The morphological classification includes grain shape, stem juiciness, grain color, glumes color, midrib color, glume hairiness, and grain size. However, in all surveyed areas, most of the local farmers mentioned generic names of sorghum landraces with grain color-based attributes as a classification criterion. As the present study revealed, many farmers were not aware on how to identify details of the botanical classification. Vernacular names are therefore simple and easily understood by farmers, and the names were meant to give credit to the consumers/local farmers. The vernacular names are also important to distinguish and maintain the identity of each sorghum landrace. Farmers also attach special names when there are attributes acquired from sorghum landraces (Figures 2 and 3 and Tables 3 and 4).Unlike the botanical classification, which is mostly hierarchical and purely taxonomic, the folk classification accommodates ethno botanical, biocultural heritage, utilitarian, psychological, and ethno linguistic factors along with the taxonomic features [42-46].

In the present study, farmers perceived genetic erosion as the loss of sorghum landrace genetic diversity with reference to number and type. It is the loss of sorghum 
TABLE 3: Proportion of local farmers citing local sorghum grains for home consumption preferences in all surveyed areas.

\begin{tabular}{lcccccc}
\hline \multirow{2}{*}{ Preference for home use } & \multicolumn{3}{c}{ Local sorghum grains } & \multicolumn{2}{c}{ Average consumption } \\
& Zengada & Chibna & Wotere & Merar & Others & $\mathbf{5 2 . 8}$ \\
Injera making & 98.2 & 74.5 & 37.8 & 28.1 & 25.4 & $\mathbf{4 9 . 2}$ \\
Tella making & 59.2 & 72.4 & 83.2 & 14.6 & 16.9 & $\mathbf{4 9 . 2}$ \\
Porridge and other forms of foods & 76.4 & 38.4 & 48.4 & 59.5 & 24.3 & $\mathbf{4 9 . 4}$ \\
\hline
\end{tabular}

Source: local farmers during survey time, 2015/2016.

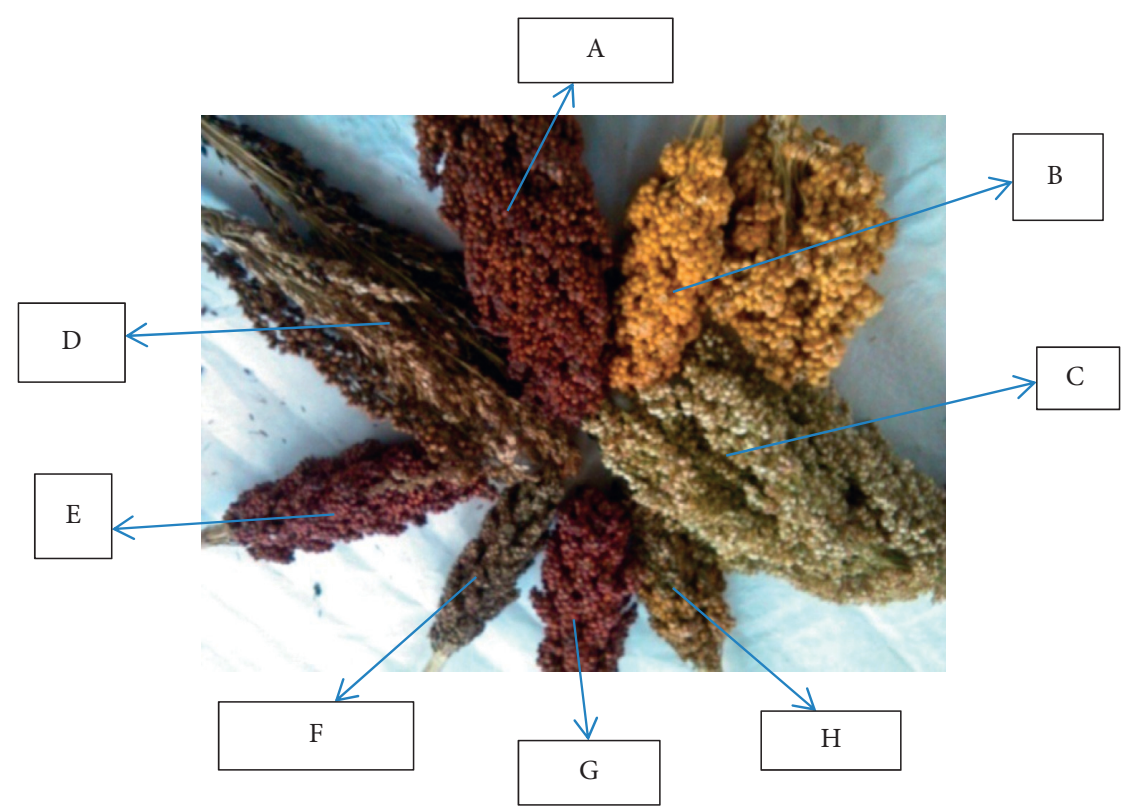

FIGURE 2: Sample representatives of sorghum landraces: Zengada (A), Wetere (B), Necho-Tinkish (C), Jofa-Tinkish (D), Nech-Mashila (H, F), and Key-Gedalit (E, G) in Tenta, Mekdela, and Delanta districts. Source: local farmers during survey time, 2015/2016.

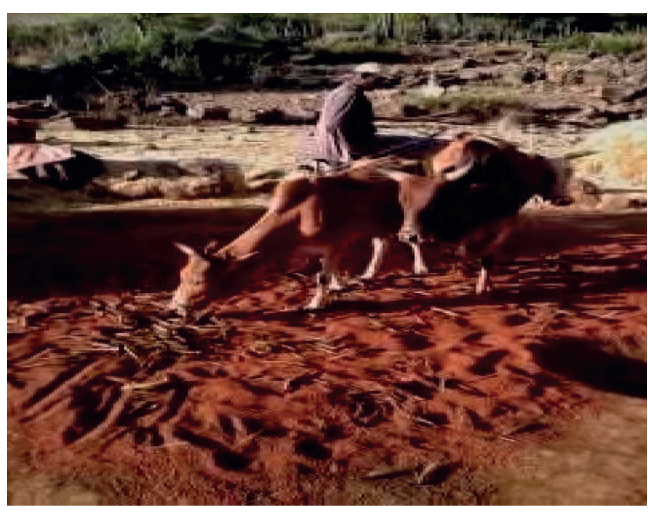

(a)

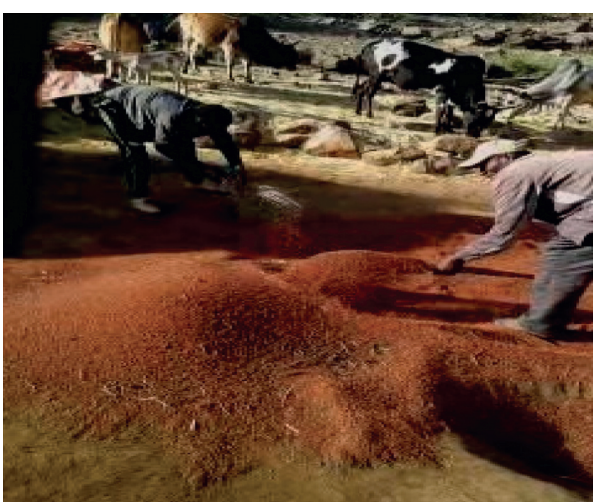

(b)

Figure 3: Traditional sorghum threshing using oxen and the popular red seeded sorghum landrace, ("Key-Mashla/Zengada") in the study areas. Source: local farmers' during field visit, 2015/2016.

landraces on farm (reduced production of sorghum landrace variety) because of multiple factors. Sometimes farmers sow a specific variety that performs well for high yield and resistance against various biotic and abiotic stresses. Thus, the numbers of sorghum landraces decline in all surveyed areas and equate the conventional sense of genetic erosion contrary to Brush [47] and Mekbib [13]. However, it is not difficult to assume that genetic erosion had occurred because the amount of land seeded to sorghum landraces was decreasing. In contrast to the present finding, Bellon et al. [48] and Brush et al. [44] indicated that there is no support for a "simple replacement theory" in the center of field crop 
TABLE 4: Estimated GE for local sorghum grains collected in the same area in 1980 and 2006-2015/2016.

\begin{tabular}{|c|c|c|c|c|c|c|c|c|c|c|c|c|}
\hline \multirow{3}{*}{$\begin{array}{l}\text { Land races on } \\
\text { the basis of } \\
\text { grain color and } \\
\text { other attributes }\end{array}$} & \multicolumn{12}{|c|}{ Provinces } \\
\hline & \multicolumn{4}{|c|}{ Tenta } & \multicolumn{4}{|c|}{ Mekdela } & \multicolumn{4}{|c|}{ Delanta } \\
\hline & $\begin{array}{c}1980^{*} \\
\text { sample } \\
\text { collected }\end{array}$ & $\begin{array}{c}2006-2015 / \\
16 \text { sample } \\
\text { collected }\end{array}$ & $\begin{array}{c}\text { GI } \\
\%\end{array}$ & $\begin{array}{c}\text { GE } \\
\%\end{array}$ & $\begin{array}{c}1980^{*} \\
\text { sample } \\
\text { collected }\end{array}$ & $\begin{array}{c}2006-2015 / \\
16 \text { sample } \\
\text { collected }\end{array}$ & GI \% & GE \% & $\begin{array}{c}1980^{*} \\
\text { sample } \\
\text { collected }\end{array}$ & $\begin{array}{c}2006-2015 / \\
16 \text { sample } \\
\text { collected }\end{array}$ & $\begin{array}{c}\text { GI } \\
\%\end{array}$ & $\begin{array}{l}\text { GE } \\
\%\end{array}$ \\
\hline Red sorghum & 4 & 3 & 75.0 & 25.0 & 5 & 4 & 80.0 & 20.0 & 4 & 1 & 25.0 & 75.0 \\
\hline $\begin{array}{l}\text { Yellow } \\
\text { sorghum }\end{array}$ & 3 & 2 & 66.6 & 33.4 & 3 & 1 & 33.3 & 66.7 & 3 & 1 & 33.3 & 66.7 \\
\hline $\begin{array}{l}\text { White } \\
\text { sorghum }\end{array}$ & 3 & 1 & 33.3 & 66.7 & 2 & 0 & 0.0 & 100.0 & 3 & 1 & 33.3 & 66.7 \\
\hline $\begin{array}{l}\text { Tinkish/juicy } \\
\text { stem }\end{array}$ & 3 & 1 & 33.3 & 66.7 & 2 & 1 & 50.0 & 50.0 & 2 & 1 & 50.0 & 50.0 \\
\hline
\end{tabular}

*Accessions were collected by EBI. Source: EBI and local farmers during survey time, 2006-2015/2016.

genetic diversity. In the surveyed areas, farmers who were stopped growing few sorghum landraces do not have a seed. Thus, it was understood that what is lost at individual farmer level was happening at the community level or woreda level. Farmers attributed the loss of sorghum landraces to many factors including late maturing, market prices and demand, low yields, and home consumption preferences. In view of these suggested reasons, the assumptions of classical genetic erosion models [16] are easily violated in farming systems in the study sites, so that there would be expected coexistence rather than the competitive exclusion to be prevailing (Table 5). According to the study of Mekbib [13], the three modalities including bioecogeographic-induced genetic erosion model (biological, ecological, and geographical factors), farmer-cum-bioecogeographic-induced genetic erosion models (blend of human and natural factors), and farmer-induced genetic erosion models together have been suggested to explain the process shaping genetic erosion scenario on farm. Human-induced processes that once took hundreds or thousands of years to develop could be carried out within decades or even years [49]. According to Brush [47] and Mekbib [13], the action of both natural and conscious selection in the presence of an interaction between socioeconomic and biophysical environmental factors leads to conservation and/or replacement of plants.

\subsection{Major Reasons for Displacement of Sorghum Landraces in} the Study Areas. The relative contribution of each factor varies across space and time. However, the five most important reasons given by the farmers interviewed for the replacement (decline) of sorghum landraces were (in downward order) as follows: reduced benefits from sorghum landraces, drought, climate change, market price and demand, and reduction in land size as stated in (Table 4). Reduced benefit of sorghum landraces can be due to utilization preferences (home consumption), low yielding, and susceptibility to weed/straiga and weevil attack. Local varieties were also praised for their good resistance characteristics to weeds and storage pests. However, as farmers reported, poor management practices, i.e., irregular examinations for signs of insects, moulds, and rodents; dirtiness in and around the grain store and dusting and wetness conditions of a grain; and underprivileged physical, mechanical, and botanical pest control measures integrated with minimum use of insecticides were resulted in devastating damages during storage operations. However, well-organized harvesting, transporting, threshing, drying, cleaning, packaging, and storing procedures improve quality and quantity of sorghum landraces [5]. The present study also confirms that the IVs were not prominently suggested as a major factor for genetic erosion of sorghum landraces. Nevertheless, the main causes of genetic erosion in crops were supposed to be the replacement of farmers' varieties (FVs) by improved varieties (IVs) [17]. Another study conducted by Mekbib [13] proves IVs of sorghum are important factors for replacement of sorghum landraces merely in the lowland areas of Ethiopia. According to the study of Mekbib [13], in eastern Ethiopia, for example, only $12 \%$ of farmers have grown IVs whereas the number of farmers who have adopted IVs in the intermediate and highlands is almost nil. The present result indicated that multiple factors were responsible for FV's (farmers' varieties) genetic erosion in the study areas (Table 4). Worede and Mekbib [50] point out that several catastrophic droughts in Ethiopia caused complete crop failures and subsequently severe genetic erosion for field crop landraces that have been maintained through many generations and forced farmers to consume the seeds normally kept for planting. Teklu and Hammer [51] also reported that the famine of the mid-1980s seriously threatened Ethiopia's biological resources as a result; relief agencies became the only source of seed for planting after farmers ate their own seed or sold as food commodity in order to survive. The recurrent drought that prevailed in region of Wollo, parts of Shewa, and Northern Ethiopia, has directly or indirectly caused considerable erosion and even resulted in massive destruction of plants [52]. The year 2015/ 16 was also El Niño season in Ethiopia and becomes serious and wipes out the whole crop production which was potentially lessen growing of sorghum landraces; fortunately/ unfortunately, the study was conducted during the El Niño season. During the year 2015/16, the normal rainfall $(667 \mathrm{~mm})$ was lowered by $167 \mathrm{~mm}$ and average annual temperature $\left(25.02^{\circ} \mathrm{C}\right.$ ) was risen by $1.65^{\circ} \mathrm{C}$ as described in the long-term climate data description [53, 54]. Drought can happen at various stages, but the most important one is the terminal stress, which results in reduced seed production [55]. 
TABLE 5: Frequency and proportions of farmers citing different reasons for replacement of sorghum landraces in three districts.

\begin{tabular}{|c|c|c|c|c|c|c|c|c|}
\hline \multirow{3}{*}{ Suggested reasons } & \multicolumn{8}{|c|}{ Number of household respondents $(N=1200)$ where $N$ is total sample } \\
\hline & \multicolumn{2}{|c|}{$\begin{array}{l}\text { Tenta district } \\
\quad(n=400)\end{array}$} & \multicolumn{2}{|c|}{$\begin{array}{l}\text { Mekdela district } \\
(n=400)\end{array}$} & \multicolumn{2}{|c|}{$\begin{array}{l}\text { Delanta district } \\
\quad(n=400)\end{array}$} & \multicolumn{2}{|c|}{ Total } \\
\hline & Frequency & $\%$ & Frequency & $\%$ & Frequency & $\%$ & Frequency & $\%$ \\
\hline Reduced benefit of the landraces & 350 & 87.50 & 390 & 97.50 & 400 & 100.00 & 1140 & 95.00 \\
\hline Climate change & 330 & 82.50 & 340 & 85.00 & 400 & 100.00 & 1070 & 89.16 \\
\hline Market price and demand & 280 & 70.00 & 380 & 95.00 & 360 & 90.00 & 1020 & 85.00 \\
\hline Food quality & 243 & 60.75 & 400 & 100.00 & 300 & 75.00 & 943 & 78.58 \\
\hline Introduction of other food crops & 400 & 100.00 & 270 & 67.50 & 380 & 95.00 & 1050 & 87.50 \\
\hline Reduction in land size & 340 & 85.00 & 360 & 90.00 & 280 & 70.00 & 980 & 81.66 \\
\hline Parasitic weeds and bird damage & 328 & 82.00 & 300 & 75.00 & 290 & 72.50 & 918 & 76.50 \\
\hline Drought & 400 & 100.00 & 340 & 85.00 & 400 & 100.00 & 1140 & 95.00 \\
\hline Change in land use pattern & 290 & 72.50 & 360 & 90.00 & 283 & 70.75 & 933 & 77.75 \\
\hline Late maturity of landraces & 350 & 87.50 & 290 & 72.50 & 320 & 80.00 & 960 & 80.00 \\
\hline Land degradation & 260 & 65.00 & 400 & 100.00 & 313 & 78.25 & 973 & 81.01 \\
\hline
\end{tabular}

Note: the percentage can add up to more than 100 since there are multiple responses by farmers. The total is obtained by adding the number of respondents, to the same suggested reasons, and dividing by the total number of farmers used for the investigation. Source: local farmers during survey time, 2015/2016.

According to Erskine and Muehlbauer [56], droughts of just a single season could result in people consuming seed stocks, while successive years of drought can prompt changes in cropping patterns and the geographic distribution of crops. These changes in cropping patterns may also include the use of alternative, more drought resistant crops in preference to the traditional sorghum landraces. The study of Stephen et al. [57] showed a marked reduction in rice diversity in the northeastern Philippines from 1996 to 1998 as a result of drought due to the El Niño phenomenon in 1997 and flooding due to two successive typhoons in 1998. In the surveyed areas, the other reason for replacement of sorghum landraces was the expansion or introduction of other crops such as teff, wheat, chickpeas, and oilseed crops as these crops are high yielding and fetch a higher market, and double cropping is possible (Table 1 and Figure 4). The erratic and unstable rainfall coupled with the longer growing period of sorghum landraces also forced farmers to adopt early maturing crops that either escape or tolerate droughts. The major external forces advocate the introduction of high-yield varieties, accompanied by mechanization and major chemical inputs, as the means to increase total production and economic return. These forces change the nature of the decision-making process dramatically; the farmer is encouraged to grow highyield varieties in monoculture using inputs of fertilizer and pesticides. Farmers also believed that diverse cropping practice or/and pattern is common for most traditional crops in lowland areas and has led to a higher dependency, and they are replacing sorghum landraces (Figure 4). In general, the farmers in all the study areas had the perception that production of sorghum landraces had been significantly declined during the past three or above decades. According to the study of Gao [58], the wide spread adoption of high-yielding rice varieties had led to biological impoverish of rice germplasm. Tunstall et al. [59] pointed out that the modern world is placing a range of pressures on traditional agricultural communities and external interests (often dominated by economic or political issues) strongly impinge. The decrease in land size and area allocation for sorghum landrace production was another challenge described by local farmers. The farmers credited this decrease partly due to number of population increment in the household (on average, 6 to 7 family members per house). As stated by local farmers and Woreda Agricultural and Rural Development Office departments, the mean area allocation for sorghum landraces in 1980 and 2015/2016 was 6 "Timmad" and 3 "Timmad," respectively ( 1 ha $=6$ "Timmad" or 1 "Timmad" $=0.17 \mathrm{ha}$ ), and this is due to the fact that children who are living together with their parents could take their share later in future life. Hence, there was a tremendous reduction of sorghum area by $50 \%$ and the existing adaptation of sorghum landraces turns from asset to liability. However, few rich households had relatively large land holdings ( 1 ha) as compared to the poor households (average $0.5 \mathrm{ha}$ ). Therefore, rich farmers (large land holders) were more likely contribute to genetic loss of sorghum landraces because of intercropping patterns (Figure 4 and Table 1). Hawkes [41] also reported that smaller area in traditional crops reduces its diversity.

As observed during field visit and interviews with Woreda Agricultural Office heads, the net cultivation area and its production too for sorghum landraces have been reduced for the period of 10/11 years (Figure 4). The present finding also indicated that mean area allocated and production for teff and wheat dramatically increased. Similarly, mean plot area allocated for oil crops and chickpea was increased (Figure 4). According to the present result, small cereals such as teff and bread wheat are at alarming rate in increasing production and partly taking over the area of sorghum (Figure 4 and Table 1). Farmers were increasingly shifted from sorghum into teff and other small cereals. Hence, sorghum landraces were produced mainly by subsistence farmers (Figures 3 and 5). Lipton and Longhurst [60] indicated that the advancing pressure of landholding specially for rich households and hardworking increases the importance of "yield" as selection criterion for farmers, leads to the intensified crop production, the adoption of other crops with higher yield potentials, and use of more inputs and the planting of more varieties on a farm. According to 


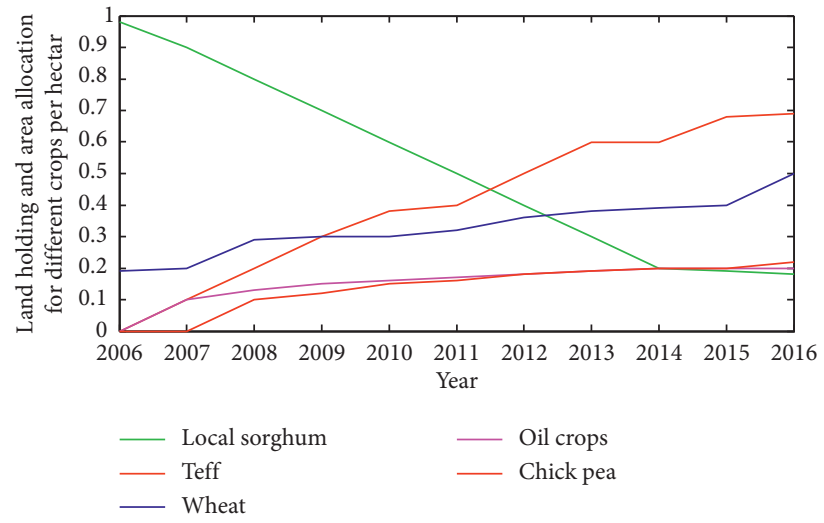

Figure 4: Trends in landholding and area allocation for different crops in 10 or 11 years for all surveyed areas. Source: Woreda Agricultural and Rural Development Offices, during the survey period, 2015/2016.

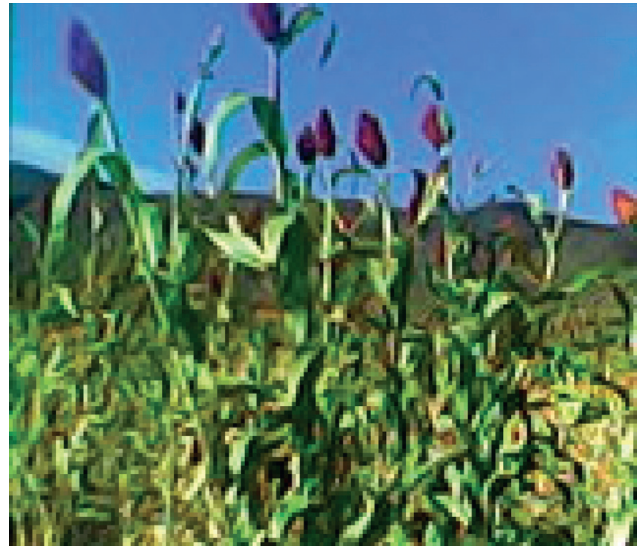

(a)

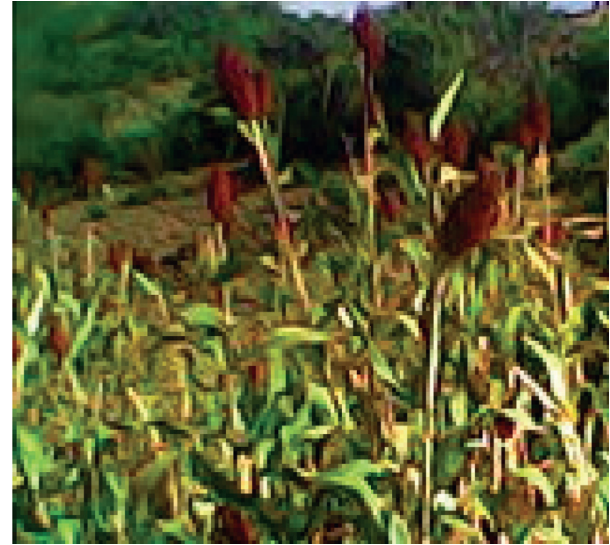

(b)

Figure 5: Agroecology of farmers' sorghum field: (a) Tenta and Delanta; (b) Mekdela districts. Source: local farmer's field during field visit, $2015 / 2016$.

Brush [16], fragmentation of landholdings allows farmers to manage several crops and hence the possibility of heterogeneous cultivation of crops in at least one field. As it has been observed during field visit, there were various restructuring processes in rural areas; particularly, agricultural lands used for settlements and construction of infrastructure-like road, schools, and health centers decrease the size of nurtured area (cultivated area). The physical fragmentation of farmers' fields may facilitate the biological fragmentation of sorghum landraces [59]. In some regions of Ethiopia, there has been gradual reduction in the overall barley production area due to the expansion of wheat and rye cultivation $[61,62]$. Genetic erosion has been also reported by Harlan [63] that there was a decreasing trend of cereal crop landrace cultivation in Turkey. Similar results in many other crops reported that FVs are rarely seen in the fields [64].

3.3. Quantifying Genetic Erosion of Sorghum Landraces in the Study Areas. However, it is challenging to put a figure on genetic erosion on the basis of the decrease in number of sorghum landraces in the study areas, and the most common means of assessing genetic erosion of field crop diversity is by counting named varieties. However, this is different from actual genetic erosion because sometimes variety name $[13,65,66]$ may not be necessarily corresponding to genetic content either geographically or over time; therefore, according to [21], genetic erosion $(\mathrm{GE})=100 \%-\mathrm{GI}$ (genetic integrity; the still extant sorghum landraces $)$; $G I=(N 2 /$ $N 1) \times 100$, where $N 1$ is the number of sorghum landraces collected in previous times and N2 is the number of presently collected sorghum landraces. It is hoped that this gives the first ever comprehensive and multidimensional analysis of genetic erosion.

3.3.1. Assessment of Genetic Erosion by Comparative Quantitative Method. Using the calculation scheme: gene erosion $=100 \%$ - gene integrity, i.e., the still extant sorghum landraces, a genetic erosion was calculated for Tenta, Mekdela, and Delanta districts. Genetic erosion of 100\% was observed in white sorghum in Mekdela and 66.7\% in Delanta and Tenta districts. Likewise, genetic erosion of red 
sorghum, $25 \%, 20 \%$, and $75 \%$, respectively, was detected in Tenta, Mekdela, and Delanta. For yellow sorghum grains, genetic erosion was 33.4\% in Tenta and 66.7\% in Mekdela and Delanta. Genetic erosion for "Tinkish" was found to be 66.7\% in Tenta and 50\% in Mekdela and Delanta (Table 5). In all surveyed areas, significant loss of sorghum landrace genetic diversity has been observed during the past 30 or above years and the process of gene erosion was still unabated, implying that there was a reduction in the number of sorghum landraces grown as other crops adopted and gene erosion undergoes (Tables 4 and 5 and Figure 4). In the same way, the two case studies conducted by Hammer et al. [21] to estimate genetic erosion in several crop landraces were found to be $72.4 \%$ in Albania and $72.8 \%$ in South Italy. The study of 220 cereal crop landraces with 147 forms in South Korea [67] showed a medium gene erosion of 74\%. Contrary to the present study, the findings of Xolocotzi [68] refuted genetic erosion of maize in Mexico in the center of diversity. The study of Gebrekidan [69] also indicated that Ethiopia has a narrow genetic base for lowland sorghum landraces. According to Hammer et al. [70], there has been significant loss of field crop genetic diversity during the past 100 years and the process of gene erosion continues.

\subsubsection{Assessment of Genetic Erosion: Household Survey} Result. Numbers of farmers growing sorghum landraces were drastically decreased in all surveyed areas in the past three or above decades. As the key informants revealed, a small number of farmers have sown some of the local varieties that provide better yield and drop less performing ones, as a result, changing varietal portfolios in the agricultural system (Figures 2, 3 and 5). In addition, the focused group discussion held in various sites with farmers manifested that there was significant variation with the types of traditional sorghum varieties they grew in the past and now. It was also indicated that from the passport data, samples were collected with high accession number and species name, but vice-versa during interview and field observation. The present finding showed that genetic erosion was nonstop and a driving force behind a change of varietal (sorghum landrace) portfolio among farming communities because of the commonness of heterogeneity in socioeconomic and biophysical environments in the farming systems. On one hand, local sorghum varieties such as "Kokita," "Merar," "Marchuke," "Amelse-Tinkish," "Mali-Tinkish" and "Sererge-Tinkish," and "Fesho" have been vanished by different reasons from farmers' farm. However, losses of sorghum landraces from the study sites do not totally mean the disappearance of landraces at zonal level. On the other hand, a number of sorghum landraces that include "Chibna," "Wotere," and "Tinkish" ("Necho-Tinkish" and "Jofa-Tinkish"), "Zengada," and "Key-Gedalit" are being grown in the study area (Figure 2). In general, sorghum landrace populations adapted to local agroclimatic conditions which are named, selected, and maintained by traditional farmers to meet their social, economic, cultural, and ecological needs were harshly condensed. Thus, sorghum landraces need to be controlled to increase survival. The present study is against the results of Mekbib [13] who reported the absence of genetic erosion of sorghum in Ethiopia. However, he has recognized the presence of ecotype differentiation [71] of varieties and also in growing specific varieties per farmers' village. As opposed to Mekbib [13], there was rivalry rather than complementarity between ex situ and in situ conservation strategies all over the study areas. Farmers' choices for desirable agronomic traits are major forces in shaping the dynamics of the crop plant population on a farm land $[11,72,73]$. The threats to field crop diversity only become visible later, as when the American plant explorers [74] recognized the problem of genetic erosion in cereal crops.

\section{Conclusions}

The present study shows the presence of genetic erosion. In this study, the top most important factors possibly leading to genetic erosion were the reduced benefits from the landraces and the presence of draught. In all surveyed areas, the numbers of FVs for three or above decades were under greater threats of extinctions. However, currently only "Zengada," "Chibna," "Key-Gedalit," "Wetere," and "Tinkish" ("Necho-Tinkish" and "Jofa-Tinkish") are being grown by farmers on small plots of land. The estimated loss accounts: $100 \%$ was observed in white sorghum in Mekdela and $66.7 \%$ in Delanta and Tenta districts. Likewise, genetic erosion of red sorghum, $25 \%, 20 \%$, and $75 \%$, respectively, was detected in Tenta, Mekdela, and Delanta. For yellow sorghum grains, genetic erosion was $33.4 \%$ in Tenta and $66.7 \%$ in Mekdela and Delanta. Genetic erosion for "Tinkish" was found to be $66.7 \%$ in Tenta and $50 \%$ in Mekdela and Delanta (Table 5). Farmers perceived some of sorghum landraces have been lost from their farm land/ home. However, losses of sorghum landraces from the study sites do not totally mean the disappearance of landraces at zonal level. Those sorghum landraces may survive and can be grown somewhere in other areas or boundaries. There are sociocultural, economic, and biological reasons that limit the use of FVs of sorghum and hence the production. Some of these were home consumption preferences, high yielding, and market demand which pressed farmers to produce oil crops, chickpea crops, teff, and wheat. However, the wealth of traditional sayings, poems, and songs gives a picture of the importance of local sorghum in society's daily life and growers show their feeling and expressions linked with sorghum production. For example, in Amharic language, they said that "Chibna Wulsera Egirun Lemagedo Erasun Letella" which means the stalk is used for fuel wood consumption and the "head part" which is the grain used for "Tella" (local drink) preparations. Finally, the natural and conscious selections have been suggested to explain the process shaping genetic erosion scenario on farm. These include farmer-induced genetic erosion model, bioecogeographic-induced genetic erosion model, and farmer-cumbioecogeographic-induced genetic erosion model.

\section{Data Availability}

The data used to support the findings of this study are included within the article. 


\section{Ethical Approval}

All procedures performed in studies involving human participants and plants were in accordance with the ethical standards of the institutional and national research committee. The Code of Ethics of the International Society of Ethno biology (ISE) was also taking into consideration.

\section{Consent}

Informed consent was obtained from all individual participants included in the study.

\section{Conflicts of Interest}

The authors declare that they have no conflicts of interest.

\section{Acknowledgments}

The authors are grateful for the kind cooperation of farmers in the areas studied for their participation and sharing their ideas and knowledge on the different aspects of sorghum landraces. The field assistants who helped during interview of farmers and field assessment are also highly appreciated.

\section{References}

[1] N. I. Vavilov, Five Continents, IPGRI, Rome, Italy, 1997.

[2] M. Worede, "Ethiopian in situ conservation," in Plant Genetic Conservation. The In Situ Approach, N. Maxted, Ed., pp. 290-301, Springer, Berlin, Germany, 1997.

[3] E. I. Adeyeye and A. J. Adesina, "Enhanchement of lipid quality of raw Guinea corn (sorghum bicolor) grains through germination and steeping," Open Journal of Analytical Chemistry Research, vol. 1, no. 1, pp. 5-17, 2013.

[4] A. Sher, L. Barbanti, M. Ansar, and M. A. Malik, "Growth response and plant water status in forage sorghum [Sorghum bicolor (L.) Moench] cultivars subjected to decreasing levels of soil moisture," Australian Journal of Crop Science, vol. 7, pp. 801-808, 2013.

[5] FAO, FAO Statistical Database, FAO, Rome, Italy, 2012, http://www.fao.org.

[6] L. R. House, “A guide to sorghum breeding," International Crop Research Institute for Semi-arid Tropics (ICRISAT), Patancheru, AP, India, 1978.

[7] W. D. Clayton, "Proposal to conserve the generic name sorghum Moench (gramineae) versus sorgum adans. (Gramineae)," Taxon, vol. 10, no. 8, pp. 242-243, 1961.

[8] J. R. Harlan and J. M. de Wet, "A simplified classification of cultivated sorghum 1," Crop Science, vol. 12, no. 2, pp. 172-176, 1972.

[9] A. B. L. Stemler, J. R. Harlan, and J. M. J. de Wet, "The sorghums of Ethiopia," Economic Botany, vol. 31, no. 4, pp. 446-460, 1977.

[10] T. Tessema and E. Bechere, "Developing elite durum wheat landrace selections (composites) for Ethiopian peasant farm use: raising productivity while keeping diversity alive," Euphytica, vol. 102, pp. 323-328, 1998.

[11] J. R. Harlan, Crops and Man, The American Society of Agronomy, Inc. and the Crop Science Society ofAmerica, Inc., Madison, WI, USA, 1975.

[12] M. Worede, "SOS/E: promoting farmers' seed-its conservation, enhancement and effective utilization," in Proceedings of the SSC-Africa Project Workshop, Harare, Zimbabwe, September 1998.

[13] F. Mekbib, "Genetic erosion of sorghum (Sorghum bicolor (L.) Moench) in the centre of diversity, Ethiopia," Genetic Resources and Crop Evolution, vol. 55, no. 3, pp. 351-364, 2008.

[14] S. B. Brush, "In situ conservation of landraces in centers of crop diversity," Crop Science, vol. 35, no. 2, pp. 346-354, 1995.

[15] O. T. Solbrig, "The origin and function of biodiversity," Environment, vol. 33, pp. 17-38, 1991.

[16] S. B. Brush, "Genetic erosion of crop populations in the centres of diversity: a revision," in Proceedings of Technical Meeting on the Methodology of the FAO World Information and Early Warning System on Plant Genetic Resources, Research Institute of Crop Production, Prague, Czech Republic, June 1999.

[17] FAO, The State of the World's Plant Genetic Resources for Food and Agriculture, FAO, Rome, Italy, 1998.

[18] H. Shewayrga, D. R. Jordan, and I. D. Godwin, "Genetic erosion and changes in distribution of sorghum (Sorghum bicolor L. (Moench)) landraces in north-eastern Ethiopia," Plant Genetic Resources: Characterization and Utilization, vol. 6, no. 1, pp. 1-10, 2006.

[19] J. Provan, J. R. Russell, A. Booth, and W. Powell, "Polymorphic chloroplast simple sequence repeat primers for systematic and population studies in the genus Hordeum," Molecular Ecology, vol. 8, no. 3, pp. 505-511, 1999.

[20] M. Akimoto, Y. Shimamoto, and H. Morishima, "The extinction of genetic resources of Asian wild rice, Oryza rufipogon Griff: a case study in Thailand," Genetic Resources and Crop Evolution, vol. 46, no. 4, pp. 419-425, 1999.

[21] K. Hammer, H. Knüpffer, L. Xhuveli, and P. Perrino, "Estimating genetic erosion in landraces? Two case studies," Genetic Resources and Crop Evolution, vol. 43, no. 4, pp. 329-336, 1996.

[22] L. Guarino, J. Serwinski and Faberova, Approaches to measuring genetic erosion," in Proceedings of the Technical Meeting on the Methodology of the FAO World Information and Early Warning System on Plant Genetic Resources, pp. 26-28, Research Institute of Crop Production, Prague, Czech Republic, June 1999.

[23] L. O. de Oliveira and E. R. Martins, "A quantitative assessment of genetic erosion in ipecac (Psychotria ipecacuanha)," Genetic Resources and Crop Evolution, vol. 49, pp. 607-617, 2002.

[24] M. Worede, "An Ethiopian perspective on conservation and utilization of plant genetic resources," in Plant Genetic Resources of Ethiopia, J. M. M. Engels, J. G. Hawkes, and M. Worede, Eds., pp. 3-19, Cambridge University Press, Cambridge, UK, 1991.

[25] M. Worede, T. Tesemma, and R. Feyissa, "Keeping diversity alive: an Ethiopian perspective," in Genes in the Field: onFarm Conservation of Crop Diversity, C. Fowler, G. C. Hawtin, and T. Hodgkin, Eds., pp. 143-161, CRC Press, Boca Raton, FL, USA, 2000.

[26] M. Worede, "Ethiopia: a genebank working with farmers," in Growing Diversity, D. Cooper, R. Vellve, and H. Hobbelink, Eds., pp. 78-94, Intermediate Technology Publications, London, UK, 1992.

[27] ESIP, Ethiopian Sorghum Improvement Project, Progress Report No. 5, ESIP, Madison, WI, USA, 1977.

[28] ESIP, Ethiopian sorghum improvement project, Progress Report, No. 6, ESIP, Madison, WI, USA, 1978.

[29] N. I. Vavilov, Studies on the Origin of Cultivated Plants, State Press, Leningrad, Russia, 1926. 
[30] N. I. Vavilov, "The origin, variation, immunity, and breeding of cultivated plants," Selected Writings of N.I. Vavilov, Chronica Botanica, Waltham, MA, USA, 1951.

[31] J. R. Harlan, "Ethiopia: a center of diversity," Economic Botany, vol. 23, no. 4, pp. 309-314, 1969.

[32] P. L. Leberg, "Effects of population bottlenecks on genetic diversity as measured by allozyme electrophoresis," Evolution, vol. 46, no. 2, pp. 477-494, 1992.

[33] O. H. Frankel and M. E. Soule, Conservation and Evolution, Cambridge University Press, Cambridge, UK, 1981.

[34] FAO, Food and Agriculture Organization of the United Nations, State of the World's Plant Genetic Resources for Food and Agriculture, Rome, Italy, 1997.

[35] CSA, National Statistics (Abstract) of the Central Statistics Agency of Ethiopia, Central Statistical Agency, Ethiopia, 2007.

[36] F. Hailu, "Farmers perception of pesticide use and genetic erosion of landraces of tetraploid wheat (Triticum spp.) in Ethiopia," Genetic Resources and Crop Evolution, vol. 64, no. 5, pp. 979-994, 2016.

[37] I. S. Bisht, P. S. Mehta, and D. C. Bhandari, "Traditional crop diversity and its conservation on-farm for sustainable agricultural production in Kumaon Himalaya of Uttaranchal state: a case study," Genetic Resources and Crop Evolution, vol. 54, no. 2, pp. 345-357, 2007.

[38] N. Ahmed, J.-E. Englund, I. Åhman, M. Lieberg, and E. Johansson, "Perception of pesticide use by farmers and neighbors in two periurban areas," Science of The Total Environment, vol. 412-413, pp. 77-86, 2011.

[39] SAS, Statistical Analysis System, SAS Institute, Inc. Cary, NC, USA, 1997.

[40] E. Mutegi, F. Sagnard, M. Muraya et al., "Ecogeographical distribution of wild, weedy and cultivated Sorghum bicolor (L.) Moench in Kenya: implications for conservation and crop-to-wild gene flow," Genetic Resources and Crop Evolution, vol. 57, no. 2, pp. 243-253, 2009.

[41] J. G. Hawkes, The Diversity of Crop Plants, Harvard University Press, Cambridge, MA, USA, 1983.

[42] B. Berlin, D. E. Breedlove, and P. H. Raven, "General principles of classification and nomenclature in folk biology," American Anthropologist, vol. 75, no. 1, pp. 214-242, 1973.

[43] B. Berlin, D. E. Breedlove, and P. H. Raven, Principles of Tazetal Plant Classification. An Introduction to the Botanical Ethnography of a Mayan-Speaking People of Highland Chiapas, Academic Press, New York, NY, USA, 1974.

[44] S. B. Brush, H. J. Carney, and Z. Humán, "Dynamics of Andean potato agriculture," Economic Botany, vol. 35, no. 1, pp. 70-88, 1981.

[45] E. Hunn, "The utilitarian factor in folk biological classification," American Anthropologist, vol. 84, no. 4, pp. 830-847, 1982.

[46] G. J. Martin, Ethnobotany, Chapman \& Hall, London, UK, 1995.

[47] S. B. Brush, "The issues of in situ conservation of crop genetic resources," in Genes in the Field: On Farm Conservation of Crop Diversity. IPGRI and IDRC, S. Brush, Ed., pp. 3-28, Lewis Publishers, Boca Raton, FL, USA, 2000.

[48] M. R. Bellon, J. L. Pham, and M. T. Jackson, "Genetic conservation: a role for rice farmers," in Plant Genetic Conservation-the in Situ Approach, N. Maxted, B. V. Ford-Lloyd, and J. G. Hawkes, Eds., pp. 263-289, Chapman \& Hall, London, UK, 1997.

[49] K. Hammer, "Resolving the challenge posed by agrobiodiversity and plant genetic resources-an attempt,"
Journal of Agriculture and Rural Development in the Tropics and Subtropics, vol. 76, p. 184, 2004.

[50] M. Worede and H Mekbib, "Linking genetic resource conservation to farmers in Ethiopia," in Cultivars Knowledge, W. de Boef, K. Amanour, K. Wellard, and A. Bebbington, Eds., pp. 78-84, Intermediate Technology Publications, London, UK, 1993.

[51] Y. Teklu and K. Hammer, "Farmers' perception and genetic erosion of tetraploid wheats landraces in Ethiopia," Genetic Resources and Crop Evolution, vol. 53, no. 6, pp. 1099-1113, 2006.

[52] IBC, National Biodiversity Strategy Action Plan (NBSAP), Institute of Biodiversity Conservation, Addis Ababa, Ethiopia, 2005.

[53] R. Singh, M. Worku, S. Bogale et al., "Reality of resilience: perspectives of the 2015-16 droughts in Ethiopia," BRACED Resilience Intel, 2016, https://reliefweb.int/report/ethiopia/ reality-resilience-perspectives-2015-16-drought-ethiopia.

[54] A. Gezahegn, "Long-term climate data description in Ethiopia," Data in Brief, vol. 14, pp. 371-392, 2017.

[55] F. Mekbib, "Farmer and formal breeding of sorghum (Sorghum bicolor (L.) Moench) and the implications for integrated plant breeding," Euphytica, vol. 152, no. 2, pp. 163-176, 2006.

[56] W. Erskine and F. J. Muehlbauer, "Effects of climatic variations on crop genetic resources and plant breeding aims in West Asia and North Africa," in Climatic Change and Plant Genetic Resources, M. T. Jackson, B. V. Ford-Lloyd, and M. L. Parry, Eds., Belhaven Press, London, UK, 1990.

[57] R. M. Stephen, M. Calibo, M. Garcia-Belen, J. L. Pham, and F. Palis, "Natural hazards and genetic diversity in rice," Agriculture and Human Values, vol. 19, pp. 133-149, 2002.

[58] L. Z. Gao, "The conservation of Chinese rice biodiversity: genetic erosion, ethnobotany and prospects," Genetic Resources and Crop Evolution, vol. 50, pp. 17-32, 2003.

[59] V. Tunstall, A. Teshome, and J. K. Torrance, "Distribution, abundance and risk of loss of sorghum landraces in four communities in North Shewa and South Welo, Ethiopia," Genetic Resources and Crop Evolution, vol. 48, no. 2, pp. 131-142, 2001.

[60] M. Lipton and R. Longhurst, New Seeds and Poor People, Johns Hopkins University Press, Baltimore, MD, USA, 1989.

[61] J. Leur and H. Gebere, "Diversity between some Ethiopian farmer's varieties of barley and within these varieties among seed sources," Genetic Resources and Crop Evolution, vol. 50, pp. 351-357, 2003.

[62] W. Mekonen, Tanto, and T. F. Regassa, "Keeping diversity alive: an Ethiopian perspective," in Genes in the Field: OnFarm Conservation of Crop Diversity. IDRC and IPGRI, S. B. Brush, Ed., pp. 143-161, Lewis Publishers, Boca Raton, FL, USA, 2000.

[63] J. R. Harlan, "Collection of crop plants in Turkey, 19484," Agronomy Journal, vol. 42, no. 5, pp. 258-259, 1950.

[64] B. Tsegaye and T. Berg, "Genetic erosion of Ethiopian tetraploid wheat landraces in Eastern Shewa, Central Ethiopia," Genetic Resources and Crop Evolution, vol. 54, no. 4, pp. 715-726, 2007.

[65] F. Mekbib, "Infra-specific folk taxonomy in sorghum (Sorghum bicolor (L.) Moench in Ethiopia: folk nomenclature, classification, and criteria," Journal of Ethnobiology and Ethnomedicine, vol. 3, no. 1, 2006.

[66] F. Mekbib, "Farmers' seed system of sorghum (Sorghum bicolor (L.) Moench) in the center of diversity II: seed quality, 
storage, protection and security," Journal of New Seeds, vol. 8, no. 3 , pp. $63-86,2007$, In press.

[67] W. S. Ahn, H. J. Kang, and M. S. Yoon, "Genetic erosion of crop plants in Korea," in Biodiversity and Conservation of Plant Genetic Resources in South Asia, Y. G. Park and S. Sakamoto, Eds., pp. 41-55, Japan Scientific Societies Press, Tokyo, Japan, 1996.

[68] E. H. Xolocotzi, "Maize and man in the Greater Southwest," Economic Botany, vol. 39, pp. 416-43, 1985.

[69] B. Gebrekidan, "Salient features of the sorghum breeding strategies used in Ethiopia," Ethiopian Journal of Agricultural Science, vol. 3, no. 2, pp. 97-104, 1981.

[70] K. Hammer, N. Arrowsmith, and T. Gladis, "Agrobiodiversity with emphasis on plant genetic resources," Naturwissenschaften, vol. 90, no. 6, pp. 241-250, 2003.

[71] F. Mekbib, "Farmer breeding of (Sorghum bicolor (L.) Moench) in the center of diversity: I socioecotype differentiation, varietal mixture and selection efficiency," Journal of New Seeds, vol. 9, no. 1, pp. 43-67, 2007.

[72] J. M. J. de Wet and J. P. Huckabay, "The origin of sorghum bicolor. II. Distribution and domestication," Evolution, vol. 21, no. 4, pp. 787-802, 1967.

[73] O. H. Frankel, "Genetic conservation: our evolutionary responsibility," Genetics, vol. 78, no. 1, pp. 53-65, 1974.

[74] H. R. Harlan and M. L. Martini, Problems and Results of Barley Breeding, USDA Yearbook of Agriculture, US Government Printing Office, Washington, DC, USA, 1936. 